\author{
O.Є. CIUKOPI3
}

\title{
АНАЛІТИЧНЕ ДОСЛІДЖЕННЯ МІЖНАРОДНОГО ДОСВІДУ ОРГАНІЗАЦІї МЕДИЧНОЇ ПІСЛЯДИПЛОМНОЇ ОСВІТИ
}

\author{
Львівський національний медичний університет імені Данила Галицького, м. Львів, Україна
}

\begin{abstract}
Мета: аналітичне дослідження та вивчення досвіду організації післядипломної медичної освіти в різних країнах світу для підвищення рівня післядипломної освіти в Україні.

Матеріали і методи. У роботі проведено аналітичне дослідження літературних джерел міжнародного досвіду організації післядипломної освіти у світі.

Результати. Як відомо, що в провідних країнах світу досвід підготовки фрахівців у медичній галузі відрізняється від українського як за змістом, так і за обсягом. Структура медичної післядипломної освіти фрормується від моделі системи охорони здоров'я в кожній країні, структури національної системи охорони здоров'я, її фрінансування, економічного розвитку країни та рівня культури. Все це призводить до деяких термінологічних відмінностей і відносності при порівнянні навчальних процесів.

Висновки. У розвинутих країнах світу рівень післядипломної освіти є доволі високим, проте сьогодні спостерігають певну її стагнація та інертність, що перешкоджає її прогресу та удосконаленню відповідно до сучасних умов, які невпинно змінюються. Програми підготовки профресіонала-фрахівця у розвинутих країнах $\epsilon$ більш різноманітні. Університети постійно пропонують широкий спектр програм підготовки.
\end{abstract}

КЛЮЧОВІ СЛОВА: післядипломна освіта; модель підготовки лікарів; резидентура; індикатор знань; організація охорони здоров'я.

Післядипломна медична освіта у світі є структурною складовою організації охорони здоров'я країн, що використовують міжнародний досвід у навчанні та набутті практичного досвіду. Основним завданням післядипломної медичної освіти є підготовка лікаря-фрахівця, яку фрормують в результаті безперервної професійної якісної медичної освіти, постійної роботи над собою та практичної діяльності [34]. Що ж стосується нашої держави - України, то післядипломна підготовка медиків сьогодні характеризується ризиком однобічного розвитку та недостатньою обізнаністю і загалу медичної спільноти.

Достатньо важливою для постійного вдосконалення підготовки медичного фрахівця є командна робота, тобто залучення до навчання не лише академічних викладачів, але й провідних лікарівклініцистів [31]. При навчанні слід враховувати вимоги, які висувають до фахівця (орієнтованість на результат), мотивування до навчання та до власної самореалізації [34].

Мета роботи: аналітичне дослідження та вивчення досвіду організації післядипломної медичної освіти в різних країнах світу для підвищення рівня післядипломної освіти в Україні.

Матеріали і методи. У роботі проведено аналітичне дослідження літературних джерел міжнародного досвіду організації післядипломної освіти у світі.

Результати дослідження та їх обговорення. Сучасні американські стандарти надання медич-

(c) О.Є. Січкоріз, 2017 них послуг - одні з найвищих у світі і характеризуються високоспеціалізованою, ресурсомісткою та дороговартісною системою. Для задоволення таких стандартів рівень підготовки медичних працівників повинен відповідати найвищим критеріям. Тому підготовка лікаря у цій країні довготривалий процес, який триває навіть до 10-15 років. Американська модель підготовки медичних фахівців як у США, так і в Україні складається 3 двох частин. Першу - дипломну освіту - здобувають у медичному університеті, де отримують диплом лікаря. У США студентам, які пройшли повний курс навчання в одній з вищих медичних шкіл, присвоюють ступінь доктора медицини, але вони не мають права на самостійну практику [37]. Для того, щоб почати професійну роботу, вони зобов'язані пройти післядипломний курс підготовки у резидентурі. Лише після цього випускники отримують першу свою ліцензію на право займатися самостійною медичною практикою. Резидентуру у США проводять за певними спеціальностями. Вона включає чітко прописані години, які резидент повинен провести в університетській клініці або в первинній медичній амбулаторії, а також певну кількість годин, що відведена на лекції та семінари. Перший рік навчання резидентури називають інтернатурою. Практично весь цей рік лікарі-інтерни проводять в госпіталях. Це робота у відділеннях реанімації та інтенсивної терапії (з достатньою кількістю годин, відведених на нічні чергування) та 
в приймальному відділенні медичної університетської клініки. На другому році навчання резиденти беруть безпосередню участь у розробці плану обстеження та лікування хворих під обов'язковим наглядом лікаря, а також беруть ще участь у навчанні інтернів та студентів. На цьому етапі навчання існує можливість вибору дисциплін, які для них визначають їх подальшу діяльність. Навчання за спеціальністю «Терапія» триває 3 роки, «Хірургія» - 5 років. Кожному резиденту протягом навчання необхідно скласти іспит Step 3 USMLE, який можна складати уже з першого року навчання в резидентурі. Step 3 містить кількість питань 3 терапії, хірургії, акушерства та гінекології, педіатрії та психіатрії, а його метою є оцінка клінічних знань резидента. Після закінчення резидентури кожен лікар має право складати сертифікований іспит уже з обраної ним спеціальності (Board certification), після складання якого лікарі можуть розпочинати самостійну лікарську діяльність. Якщо лікар хоче спеціалізуватися за однією із вузьких дисциплін, то опановує вторинну спеціалізацію (Fellowship), яка триває від 1 до 5 років [9, 10]. Лише після цього випускники (лікарі-резиденти) отримують ліцензію на право займатися самостійною медичною практикою за вузькою (вторинною) спеціальністю. Вимогою для підтримання медичної ліцензії $€$ певна кількість отриманих навчальних кредитів під час проходження відповідного професійного навчання. В США це називають CME (Continuous Medical Education). Таким чином, стимулюється практичними лікарями відвідування курсів підвищення кваліфікації та наукових коноеренцій. Існує ще й окрема від ліцензії система сертифікації (Board Certification), що не є обов'язком, а яка $є$ швидше маркетинговим інструментом: сертифікат $€$ свідченням високої кваліфікації лікаря. Для його отримання потрібно скласти іспити, з періодичністю в десять років.

Друга світова війна суттєво вплинула на економічний розвиток багатьох країн Південної Азії. Залишившись після визволення від окупації Імператорської Японії військові контингенти США та Великої Британії ці країни моделювали своє суспільство за американським взірцем. Не уникнула цього феномена і охорона здоров'я. А вимога становлення та реформування національної системи охорони здоров'я отримала прямий вплив на післядипломну освіту. Найчастіше американським медичним стандартам надають перевагу країни: Індонезія, Філіппіни, Таїланд, Тайвань і Південна Корея. Медичне навчання в цих країнах дуже схоже на освіту США за методикою і триває 3-4 роки. Після завершення навчання випускник отримує сертиорікат магістра медицини. Для отримання сертиоріката фрахівця (спеціаліста) потрібно ще 3-4 роки навчатися за напрямками кардіологія, хірургія, нейрохірургія, педіатрія, внутрішня медицина.
Медична освіта деяких країн Південної Азії знаходиться під контролем Рад післядипломної підготовки лікарів в Японії. В Тайвані для оцінки професійної компетентності медичного фрахівця розроблені різні методи її оцінювання. Одним із найпоширеніших методів є об'єктивно структурована клінічна експертиза. Цей формат розроблений за схемою декількох клінічних баз (станцій), в яких лікарі виконують відповідні завдання за певний період часу [32]. Індія, Пакистан, Бангладеш, Шрі-Ланка, Бірма, Малайзія, Сінгапур, Гонконг використовує англійську модель підготовки медичних фрахівців.

На даний час навчання в Сінгапурі триває 5 років, 3 яких 2 роки - теоретична освіта, а 3 роки клінічне навчання. Медична школа використовує не лише університетські клініки для викладання клінічних дисциплін. Керівник навчання в клінічному підрозділі $€$ членом комісії при складанні підсумкового іспиту MBBS [37].

Пройшовши тернистий шлях становлення охорони здоров'я та додипломної та післядипломної медичної освіти, ці країни в останні роки показують суттєві успіхи у впровадженні прогресивних світових медичних технологій та розвивають «медичний туризм».

При цьому післядипломну підготовку частина випускників регіональних університетів проходить в кращих медичних університетах США.

Післядипломна медична освіта у Великій Британії організовується та контролюється деканами медичних університетів, а реєстрація та відповідність професійним стандартам є пріоритетом Генеральної медичної ради. Випускник, який має отримати вищу медичну освіту, протягом 5 років, враховуючи різні академічні заходи, набирає 200 СМЕ-кредитів. За відсутності такої кількості медичних освітніх кредитів спеціаліста вилучають зі списку Коледжу кваліфікованих орахівців [10].

Крім очного навчання, для підвищення кваліфікації лікарів пропонують перегляд мультимедійних презентацій на своєму робочому місці [39]. У Великій Британії в процесі післядипломної підготовки лікарів застосовують технологію мобільного навчання, яку називають m-навчанням («арps» та «adds»). М-навчання - це технологія мобільного навчання, яка передбачає ознайомлення 3 матеріалом за допомогою сучасних гаджетів. «Apps»малоінформативне навчання, яке включає комплекс знань для лікарів-практиків (інформацію про ліки, які найчастіше приймають, стандартні підходи до встановлення діагнозу, національні та місцеві протоколи лікування). «Adds» - це ручні стандарт-прилади, приєднані до мобільних установок: термометри, апаратні вимірювачі тиску, монітори роботи серця, стетоскопи та електрокардіографи, які можуть бути використані як лікарем, так і пацієнтом. За основу взято можливість 
оглядати відео з палати чи операційної на планшеті чи смартфоні, що економить час лікаря (інтерна) та резидента, забезпечує з ним зворотній зв'язок [9].

В Австралії та Новій Зеландії післядипломний сертифікат видає Royal Australasian College of Surgeons (RACS) після виконання та складання іспиту з відповідної програми навчання. Зокрема, програма з хірургічної анатомії складається 32 семестрів (6 місяців кожен). Вивчення анатомії включає 2 етапи:

- дистанційне навчання триває 24 тижні (вивчення та ознайомлення з тематичними матеріалами, відповіді на невелику кількість тестів і запитань та публікації чотирьох статей дослідницького характеру);

- підведення підсумків практичної роботи - операційні втручання (операції). Це очні двотижневі цикли - включають перебування в університетських клініках із постійним проживанням у гуртожитку.

Даний курс $є$ первинним, становить першу межу відбору для подальшої підготовки спеціалістів хірургів та радіологів. Після проходження першого етапу залишається, як правило, невелика кількість спеціалістів, які продовжують далі навчання. Відпрацювання практичних навичок на трупному матеріалі спонукає більшість із них реалізовувати можливість подальшого стажування в медицині.

У медичних навчальних закладах Австралії навчання часто відрізняється за тривалістю. Так, в університеті м. Мельбурна бажаючі отримати післядипломний сертифікат із хірургічної анатомії набувають практичних навичок, необхідних для проходження курсу. Перший семестр нараховує 18 тижнів (160 год). Курс складається з лекцій, виконання домашніх завдань та практичних занять у секційному залі, відсутнє на цьому етапі дистанційне навчання. Одним трупом займаються шестеро стажистів, при цьому одночасно працюють троє 3 наступною ротацією. У таких заняттях зацікавлені як майбутні анатоми, радіологи, так і хірурги. В університеті м. Аделаїда такий курс триває 24 тижні, складається 3 лекцій та практичних занять. Курс поділено на 3 модулі, кожен 3 яких триває 8 тижнів. Щотижня протягом 3 год ті, які навчаються, вивчають препарати з секційного матеріалу. Курс післядипломного навчання в Австралії закінчується підтвердженням його проходження представниками RACS, що підтримують даного спеціаліста орінансово [6, 36]. Форма проходження циклів післядипломного навчання в Австралії $€$ співзвучною 3 університетськими клініками інших країн.

У Новій Зеландії та Австралії існують наступні методи оцінювання знань: тестування (враховується баланс між формальною та сумарною оцінками) та іспити - визначення рівня теоретичних знань, спеціальний тип іспиту - об'єктивно клінічний іспит, який проводять у формі діалогу стажера та інструктора/керівника. Результати іспитів свідчать як про рівень знань та вмінь стажера, так і про рівень викладання/навчання. Найкраще це можуть оцінити зовнішні аудитори [6, 11, 25, 30, 31, 36].

Урядові медичні організації у Канаді та Австралії (на зразок Australian Health Ministers' Advisory Counsil (AHMAC) моніторять стан післядипломної медичної освіти за співвідношенням рівня оволодіння практичними навичками та результатом його застосування на практиці. Цей моніторинг включає контроль за: 1 - якістю: університетські медичні програми повинні бути розраховані на добрий результат; 2 - здатністю до практичної діяльності та наявністю основного клінічного стажу (враховується в Генеральній реєстрації); 3 - частотою проходження чергових професійних тренінгів. Університетські медичні програми відразу орієнтовані на ефективність навчання, яке має бути гнучким і змінюватися відповідно до досягнень в медичній науці. Сертифікація стосується як навчальних програм, так і самих фрахівців згідно з результатами перевірки основних практичних навичок після проходження професійного тренінгу [27].

У Канаді щодо післядипломної освіти лікарів існують такі урядові рекомендації: співпраця, колегіальність, вміння знаходити консенсус у вирішенні спірних питань, фокусування уваги суспільства на медичних школах та лікарнях [7, 37]. Канадська програма реабілітації анестезіологів незабаром перейде до CFHS для підвищення прозорості, відповідальності, справедливості та безпеки пацієнтів [12].

Вища медична освіта Нідерландів на даний час перебуває у стадії реформи післядипломної медичної освіти (reform post graduate medical education - PGME). Ïї результатом повинна стати нова система акредитації для медичних університетів, які займаються тренінгом лікарів та клініцистів-викладачів. Первинно їх увага в основному була зосереджена на практичних навичках. У майбутньому цей стиль має змінитися, потрібно досягти балансу між теоретичним навчанням та оволодінням практичними навичками. За основу беремо модель післядипломної освіти Данії, опубліковану Frenkiз зі співавторами (2010р.) У ній описані історичні стадії розвитку медичної освіти, стан на сьогодні і перспективи на майбутнє. Перша стадія - інформативна, торкається підготовки медичного експерта. Медичний експерт повинен мати загальні знання, практичні навички (вміння встановлювати діагноз та призначати лікування в рамках однієї спеціальності). Друга стадія - формативна (творча), забезпечує підготовку професіонала, який має певний досвід у доказовій медицині, вміє співпрацювати з іншими фахівцями та органами охорони здоров'я [28, 33].

У Нідерландах освіта, метою якої є підготовка високоспеціалізованого медичного професіонала, включає володіння лікарем сучасних ІТ-технологій та обов'язково містить соціальні аспекти. 
Профресіонал повинен знати не тільки внутрішні проблеми медичної установи, але й враховувати вплив суспільства на неї, відчувати, чи задоволене суспільство їх роботою. І тому сьогодні у Нідерландах післядипломна освіта має назву «трансорормоване (перетворююче)» навчання. Вона охоплює освітню, а також вивчає взаємозв'язки між медичними та соціальними дисциплінами. Навчання лікаря складається 3 його участі у професійних дискусіях, проспективних наукових дослідженнях і містить психологічні аспекти, а саме виховання відповідальності за сумлінне виконання своїх обов'язків. Така система підготовки на своєму шляху зустрічається 3 певними проблемами при іiі виконанні. Це нехтування проблемами охорони здоров'я та недооцінювання трансдисциплінарного підходу до діагностики та лікування. Наступною проблемою $є$ потреба затвердження запропонованих заходів та підходів у фрормі ефективних діагностично-лікувальних алгоритмів на основі сучасної медичної освіти і науки. Післядипломна медична тренінгова програма із соціологічним акцентом потребує серйозної урядової підтримки, що включає: відповідний менеджмент, «контактне» адміністрування, прозоро працююче керівництво та ефрективне асигнування [28].

Структура післядипломної медичної освіти у Данії має в основі базове клінічне навчання протягом 12 місяців, що $€$ аналогом інтернатури та необхідною умовою післядипломної медичної підготовки. Якщо лікар бажає здобути фрах із вузької спеціальності (дерматологію, венерологію, ревматологію, оториноларингологію та ін. ), він проходить первинно-основний тренінг - 48-60 місяців. Лікарі стажуються в державних шпиталях, де вони мають змогу спілкуватись із широким колом пацієнтів. Далі у програму післядипломного навчання входить робота у приватних госпіталях, участь у наукових пілотних проектах та розробка нових напрямків діяльності приватних госпіталів. Тривалість та організація цього навчання може змінюватись. Загалом весь навчальний процес відбувається під наглядом головного лікаря госпіталю. Він зі своєї сторони пропагує стажування в імітаційно-тренувальних кабінетах із використанням франтомів. Рекомендовано реальні хірургічні втручання на лабораторних тваринах [38].

У країнах Азії між медичними навчальними програмами існують суттєві відмінності. Програми поділяють на три типи: А - британська модель; Б - американська модель; С - європейська модель.

Індія, Пакистан, Бангладеш, Шрі-Ланка, Бірма, Малайзія, Сінгапур і Гонконг у післявузівській підготовці надають перевагу англійській системі. Однак, усі ці країни мають свої програми, де менше значення відведено лікарю-наставнику у вузькій спеціалізації та передбачено ротацію змін місця роботи для здобуття більш широкого досвіду.
Різні програми та коледжі в Омані прагнуть отримати акредитацію від однієї 3 трьох країн: США, Канади та Великої Британії [2].

В Індії існує безперервна професійна освіта практикуючого лікаря, де певні інститути післядипломної освіти здійснюють навчання. Самоосвіта лікарів відбувається також шляхом проходження дистанційного навчання за допомогою онлайн-курсів із використанням платної електронної бібліотеки [26].

В Індії зміст навчальних програм для післядипломної освіти є на $70 \%$ стандартним, а на 30 \% містить регіональні особливості та інноваційні технології. Навчальні програми переглядаються кожні 5 років. Післядипломний курс триває 2 роки, там навчаються лікарі, які бажають отримати вузьку спеціальність. Проходження курсу включає 4 періоди по 6 місяців: практична робота в госпіталі, стажування в лабораторії, виконання функцій сімейного лікаря, праця в науковому центрі [39]. Проблемою в цій країні $€$ неврегульованість джерел орінансування. Держава не може повністю їх фрінансувати, тому створено систему медичного приватного страхування та фрінансування навчання окремих категорій лікарів.

У Китаї, порівняно з Індією, уряд виділяє на охорону більше коштів. Так, за даними від 2000 р. ВОО3, Китай посідає 144 місце, а Індія - 112 за рівнем смертності. При характеристиці структури смертності встановлено, що в індійського населення спостерігаються невдалі пологи та велика частота інфекційних хвороб, чого немає у Китаї [15]. В Індії та Китаї існує поняття «суспільне здоров'я», яке $€$ міждисциплінарною галуззю, у якій працюють не лише медики-орахівці, але і соціальні працівники, психологи та ін. [17].

Підготовку лікарів різних спеціальностей у китайських медичних університетах поділяють на: базову (фундаментальну) медицину - 7-8 років; клінічну медицину - 7-8 років; профрілактичну медицину - 5 років; анестезіологію - 5 років; радіологічну медицину - 5 років; стоматологію - 5 років; біотехнології - 5 років [41]. У Китаї післядипломна медична освіта ґрунтується на моделях США та Великої Британії, що проявляється у трьохрічній резидентурі [18]. Велике значення надають самостійній роботі 3 відеоматеріалами, роботі 3 досвідченими фрахівцями-практиками, участі у конфреренціях. Найважливішою вважають роботу в клініках, де лікар набуває практичних навичок і після закінчення складає іспит. Вважають, що завдяки різноманітності фрорм очного та заочного навчання за останні 10 років профресійний рівень лікарів у Китаї значно зріс [13]. Підготовку лікарів вузького профрілю в Китаї проводять у формі циклів лекцій у вищих медичних навчальних закладах. Після закінчення лікарі відповідають на тестові завдання, що включають 200 запитань [13]. Оцінювання знань стажистів здійснюють наглядові 
органи і воно може бути як фрормальним, так і проводитись один раз стаціонарно за певний період, а також може відбуватися щодня і стосуватися дій стажиста відповідно до певної клінічної ситуації. Крім цього, лікар-стажист зобов'язаний дати оцінку своїй програмі навчання, за якою він навчався та охарактеризувати керівників-наставників [20, $22,35]$. Отже, роль клінічного лектора (викладача) в післядипломній освіті залишається дуже важливою [39]. У Китаї існує 2 типи медичної освіти: стандартизована підготовка лікаря (резидентура) та другий тип - підвищення рівня клінічної професійної підготовки. Так званий «майстер» клінічної професійної діяльності - це лікар, який навчається на робочому місці, а для підвищення його рівня профресіоналізму, виконує клінічну ротацію, під час якої він повинен не менше як 6 місяців працювати у різних відділеннях медичного закладу [41]. Щоб лікар мав перспективу кар'єрного зростання, розроблено власну номенклатуру для лікарів: молодший лікар, лікуючий лікар, помічник головного лікаря та головний лікар [19].

Цікавою є підготовка сімейного лікаря в Китаї, це 3-річна стандартизована клінічна ординатура. Однак після її закінчення вони не отримують посвідчення і тому постійно шукають роботу. Навички та підготовка сімейних лікарів, які закінчили офріційні програми, не визнаються ні пацієнтами, ні іншими лікарями. Проблемним можливо $є$ той фракт, що сімейна медицина не визнається як законна медична спеціальність [15].

У Сінгапурі кожна лікарня або департамент мають власну програму навчання, а кандидати, відповідно, певний вибір отримання післядипломної освіти. Підготовку здійснюють у 2 етапи: базовий тренінг (підготовка за спеціальностями: внутрішня медицина, хірургія, педіатрія, акушерство та гінекологія) відбувається протягом 3 років. Після цього складають іспит і присуджують ступінь магістра медицини з певної спеціальності; другий етап підвищення кваліфікації за спеціальністю. Триває 3-4 роки з певної галузі медицини, наприклад, нейрохірургії, педіатрії або внутрішньої медицини і передбачає наявність клінічного керівника-наставника. Лікар, який підвищує кваліфікацію, має вести облік своєї роботи, результати якої розглядаються відповідним комітетом, і, якщо вони визнані задовільними, стажист сертифікується як спеціаліст.

Післядипломну підготовку в Японії проводять за європейським зразком. У Японії підготовку лікаря проводять за 5 ступенями: повна підготовка з фраху, субспеціальність в рамках цього фраху, придбання певного досвіду, статус спостерігача, навчання за програмою PhD [28]. Відповідно до сучасних вимог підготовка фрахівців нейрохірургії в Японії становить 6 років. Після 4-річного теоретичного навчання випускник складає іспит і отримує ступінь MD. Обов'язковою умовою $є$ знання японської мови. Іспит для отримання національної ліцензії лікар може складати лише один раз на рік. Після отримання цієї ліцензії лікар може перейти на наступний етап навчання - 2 роки обов'язкового клінічного навчання [40].

У всіх азіатських країнах, для мешканців яких $€$ можливість пройти післядипломну підготовку в інших країнах (наприклад, США та Великій Британії), існують одні й ті ж проблеми: програма підготовки не відображає особливості структури охорони здоров'я азіатських країн, відсутнє ознайомлення із особливостями специорічних захворювань чи етнічними характеристиками пацієнтів. Тому у більшості випадків такі знання не використовують при поверненні лікаря на своє робоче місце. Наступною проблемою є знання мови. Наприклад, цікаво, повчально та корисно стажуватись в Японії, однак складно вивчити японську мову [37].

Хоча у Афрриці $€$ понад як 100 медичних навчальних закладів, досягти консенсусу з індикатора знань та стандартів навчання досі не вдалося і це $є$ найбільшою проблемою африканських країн. Африка несе тягар хвороб, а саме - хвороби, пов'язані зі злиднями, ВІЛ/СНІД, травматизмом молодих людей, особливо із військовими конорліктами. В Асриці акредитацію медичних університетів проводять не менше 1 разу на 10 років [16].

Після проведеного аналізу встановлено, що кожна країна має власні, історично складені традиції щодо фрорм та методів підготовки лікарів та подальшого їх удосконалення. Варто зазначити, що медична освіта відрізняється від інших видів освіти. Всі відмінності випливають зі структури національної системи охорони здоров'я, економічного розвитку країни та її рівня культури, що призводить до невідворотності термінологічної відмінності та відносності при порівнянні.

\section{Висновки}

Результати аналітичного дослідження літературних джерел дають право стверджувати, що в провідних країнах світу досвід підготовки медичних фахівців відрізняється від українського як за змістом, так і за обсягом. Розвиток медичної післядипломної освіти залежить від моделі системи охорони здоров'я в кожній країні. Якщо вона функціонує переважно на платній основі за умов відсутності єдиної системи державного фрінансування, то лікар сам встановлює терміни свого наступного профресійного удосконалення. Якщо орінансування охорони здоров'я здійснюють 3 держбюджету, то державні медичні установи регулюють частоту та якість навчання лікаря та відповідають за результат.

Варто враховувати, що джерело медичного та педагогічного нагляду глибоко вкорінене в моделі навчання, тому наглядові органи повинні взяти на себе організацію та керівництво навчальним процесом. Однак, не слід нехтувати відповідальністю стажистів за своє навчання [24]. Програму 
навчання потрібно будувати стратегічно в часовому просторі з урахуванням існуючих потреб у навчання та бути регульованими і модифрікованими для задоволення освітніх потреб. Інтегроване навчання має вирішальне значення в підготовці фрахівця [34]. Для оптимізації підготовки фрахівця в галузі сучасної медицини необхідно створювати та широко використовувати дистанційні програми електронного навчання та контролю знань післядипломної медичної освіти [8].

Разом із тим, сучасний стан додипломної та післядипломної медичної підготовки не дозволяє уніфрікувати навчальні програми та стандарти опанування практичними навичками в силу серйозних відмінностей між фрінансовим та соціальнополітичним становищем багатьох країн.

Незважаючи на значні реформаторські зрушення в післядипломній освіті України, чинна система підготовки сучасних спеціалістів охорони здоров'я не $є$ досконалою та потребує більш ширшого дослідження та постійного рефрормування. У зв'язку з цим, подальші наші дослідження будуть спрямовані на зіставлення загальних тенденцій системи підготовки лікарів у світі та Україні, що дасть змогу виділити найдоцільніші у використанні моделі у прогнозуванні післядипломної освіти.

\section{Список літератури}

1. Accreditation of medical education institutions. Report of a technical meeting, Schaeffergarden, Copenhagen, Denmark, 2004. $-18 \mathrm{p}$.

2. Al-Lamki N. International accreditation of postgraduate medical education: whiter its role in oman? / N. Al-Lamki,

L. Al-Lamki // Oman Medical Journal. - 2016. - Vol. 31, No. 1. - P. 341-344.

3. Balasubramaniam P. Medical education in Asia and Japan's role in it / P. Balasubramaniam // 1994. - No. 25 (3). P. 143-147.

4. Education in India and China: history, opportunities, and challenges / Sh. I. Bangdiwala, J. D. Tucker, S. Zodpey [et al.] // Public Health Reviews. - 2009. - Vol. 33 (1). - P. 204-224.

5. Bullock A. Technology in post graduate medical education: a dynamic influence on learning? / A. Bullock, K. Webb // Postgraduate Medical Journal. - 2015. - Vol. 91 (1081). - P. 646-650. DOI: http://www.medscape.cpm/viewarticle/853319_print.

6. Campbell I. S. Options for postgraduate anatomy education in Australia and New Zealand / I. S. Campbell, C. M. Fox // New Zealand Medical Journal. - 2012. - Vol. 125 (1352). - P. 64-73. http://journal.nzma.org.nz/125-1352/5121/.

7. Dai H. Family medicine training in China / H. Dai, L. Fang, R. A. Malouin [et al.] // Family Medicine. - 2013. Vol. 45 (5). - P. 341-344.

8. De Leeuw R. A. Quality specifications in postgraduate medical e-learning: an integrative literature review leading to a postgraduate medical e-learning model / R. A. De Leeuw, W. Westerman // BMC Medical Education. - 2016. - Vol. 16. P. 168. DOI:10.1186/s12909-016-0400-7.

9. DGME into the future - a report on FMEC PG activities / The Future of Medical Education in Canada - postgraduate project / (613) 730-0687. www.AFMC.CA/FMECPG

10. Farooq S. The postgraduate medical education in U.K. The system and its relevance to training and medical practice in Pakistan / S. Farooq, I. Quadir // Journal of Pakistan Medical Association. - 1997. - Vol. 9. - P. $232-236$.

11. Forsyth K. Critical importance of effective supervision in postgraduate medical education / K. Forsyth // Med. J. Aust. 2009. - Vol. 191. - P. 12-17.

12. Fraser A. B. Curriculum reform for residency training: competence, change, and opportunities for leadership / A. B. Fraser, E. J. Stodel // Can. J. Anesth. - 2016. - Vol. 63. - P. 875-884. DOI:10.1007/s12630-016-0637-7.

13. Harden R. M. Trends and the future of postgraduate medical education / R. M. Harden // Emerg. Med. J. - 2006. Vol. 23. - P. 798-802. DOI: 10.1136/emj/2005/033738.

14. Lake F. Teaching on the run tips 13: being a good supervisor - preventing problems / F. Lake, G. Ryan // Med. J. Aust. 1984. - Vol. 8. - P. 414-415.

15. Lambert T. J. R. Multimedia based computer aided learning in postgraduate medical education: The LMF (Luddide mentality Factor) as a barrier to entry Promaco Convention / T. J. R. Lambert // Reproduced by Permission. - 2004. http:// cleo.murdoch.edu.au/gen/aset/confs/iims/92/ lambert-t.html.

16. The career decision-making process of medical students and residents and the choice of specialty and practice location: How does postgraduate medical education fit in? / N. Leduc, A. Vanasse, I. Scott [et al.] // The Future of Medical Education in Canada - postgraduate project. - (613). - P. 730-0687. 241. www.AFMC.CA/FMECPG

17. Construction of the training mode of the combination of clinical medical professional degree graduate education and resident standardized training / J. Li, Q. Wu, T. Yu [et al.] // Creative Education. - 2016. - Vol. 7. - P. 802-806. http://dx.doi. org/10.4236/ce.2016.76082.

18. Li X. An analysis of the current education status and future training needs of China's rural doctors in $2011 / \mathrm{X}$. Li, J. Liu, J. Huang [et al.] // Postgrad. Med. - 2013. - Vol. 89. - P. 202-208. DOI:10.1136/postgradmedj-2012-131094.

19. Ma S. Comparison of the health system in China and India Center for Asia pacific policy / S. Ma, N. A. Sood // 2008. 44 p. Rand URL: http://www.rand.org --18

20. The 2010 Specialist trainess Survey / R. D. Mitchell, A. Markwell, R. Fielke [et al.] // MJA. - 2011. - Vol. 195 (7). - P. 382.

21. Murray D. J. Simulation-based curriculum: The breadth of applications in graduate medical education / D. J. Murray, J. R. Boulet // Journal of Graduate Medical Education. - 2012. - Vol. 4 (4). - P. 549-550. DOI: http:/dx.doi.org/10.4300/ JGME-D-12-00256.1. 
22. Nash-Stewart C. Medical training providers obtaining feedback from their trainees: what is best practice? / C. NashStewart // Prepared for the Australian Medical Council (AMC) workshop: Training Program Evaluation and Trainee Feedback 13 November 2010. http://workshop.amc.org.au/wp-content/uploads/2010/10/traine-Feedback-BestPractice-FINAL.pdf. 23. Okereke C. D. Mentoring - the trainee's perspective / C. D. Okereke // J. Accid. Emerg. Med. - 2000. - Vol. 17. P. 133-135.

24. Patel Priyank. An evaluation of the current patterns and practices of educational supervision in postgraduate medical education in the UK / Patel Priyank // Perspect. Med. Educ. - 2016. - Vol. 5. - P. 205-214. DOI:10.1007/s40037-016-0280-6. 25. Postgraduate Medical Council of Western Australia website. Education and Training page. http://www.pmcwa.health. wa.gov.au/education/diractors.cfm

26. Postgraduate medical training in Denmark - status and future perspectives (summary in English). National Board of Health. Denmark, 2012. - 20 p.

27. A descriptive analysis of medical education in China / X. Ren, J. Yin, B. Wang [et al.] // Medical Teacher. - 2008. Vol. 30. - P. 667-672.

28. Is the modernization of postgraduate medical training in the Netherlands successful? Views of the NVMO special interest group on postgraduate medical education / F. Scheele, S. Van Lulik, H. Mulder [et al.] // Medical Teacher. 2013. - 5 p. Early Online. DOI: 10.3109/0142159X.2013.849333.

29. Factor s related to post graduate retention of medical graduates in New Zealand / W. Shelker, P. Herbison, A. Belton, P. Glue // The New Zealand Medical Journal. - 2013. - Vol. 126 (1371). - P. 27-32. http: //journal.nzma.org.nz/126$1371 / 5568 /$

30. Post graduation retention of medical students from Otago and Auckland medical programs / W. Shelker, Ph. Poole, W. Bagg [et al.] // The New Zealand Medical Journal. - 2014. - Vol. 127 (1388). - P. 64-73. http://journal.nzma.org.nz/127$1388 / 5966 /$

31. Slootweg I. A. Teamwork of clinical teachers in postgraduate medical training / I. A. Slootweg // Perspect. Med. Educ. 2016. - Vol. 5. - P. 353-256. DOI:10.1007/s40037-016-0286-0.

32. Tsai J.-C. Evaluation of the effectiveness of postgraduate general medicine training by objective structured clinical examination - Pulot study and reflection on the experiences of Kaohsiung Medical University Hospital / J.-C. Tsai, K.-M. Liu // Kaohsiung J. Med. Sci. December. - 2008. - Vol. 24, No. 12. - P. 627-633.

33. Van Der Valk Paul. Quality assurance in postgraduate pathology training the Dutch way: regular assessment, monitoring of training programs but no end of training examination / Van Der Valk Paul // Virchows Arch. - 2016. - Vol. 468. P. 109-113. DOI:10.1007/s00428-015-1895-4.

34. Van Nieuwenborg L. Continuing medical education for general practitioners: a practice format / L. Van Nieuwenborg, M. Goossens // PGMJ Online First, published on February 5, 2016 as 10.1136/postgradmedj-2015-133662

35. Vickery A. Teaching on the run tips 10: giving feedback / A. Vickery, F. Lake // Med. J. Aust. - 2005. - Vol. 183 (5). P. 267-268.

36. Wilkinson T. J. Professionalism in its time and place - some implications for medical education / T. J. Wilkinson, M. L. Moore, E. M. Flynn // New Zealand Medical Journal. - 2012. - Vol. 125 (1358). - P. 64-73. http://journal.nzma.org. $\mathrm{nz} / 125-1358 / 5262 /$

37. Wilson A. Final Report - Review of Medical Intern Training (has been prepared as part of the Review of Medical Intern Training, which has been commissioned by the Australian Health Ministers' Advisory Counsil (AHMAC) / A. Wilson, A. M. Feyer // 2015. - P. 51-59.

38. World Federation for Medical Education. 2005. WHO/WFME Guidelines for Accreditation of Basic Medical Education. Geneva/Copenhagen, 2005.

39. Development of a medical academic degree system in China / L. Wu, Y. Wang, X. Peng [et al.] // Medical Education Online. - 2014. - 19 p. http://dx.doi.org/10.3402/meo.v19.23141.

40. Zhao Lin Bo. Comparison of medical education and requirements for training in the Interventional Neuroradiology in China, Japan and Korea / Zhao Lin Bo, Miyachi Shigeru // Neurointervention. - 2013. - Vol. 8. - P. 3-8. http://dx.doi. org/10.5469/neuroin.2013.8.1.3

41. Zhu J. Doctors in China: improving quality through modernization of residency education / J. Zhu, W. Li, L. Chen. http://dx.doi.org/10.1016/50140-6736(16)00582-1.

\section{References}

1. Accreditation of medical education institutions (2004). Report of a technical meeting, Schaeffergarden, Copenhagen, Denmark.

2. Al-Lamki, N., \& Al-Lamki, L. (2016). International accreditation of postgraduate medical education: Whiter its role in oman? Oman Medical Journal, 31 (1), 341-344.

3. Balasubramaniam, P. (1994). Medical education in Asia and Japan's role in it. 25 (3), 143-147.

4. Bangdiwala, Sh.I., Tucker, J.D., \& Zodpey, S. (2009). Education in India and China: History, opportunities, and challenges. Public Health Reviews, 33 (1), 204-224.

5. Bullock, A., \& Webb, K. (2015). Technology in post graduate medical education: a dynamic influence on learning? Postgraduate Medical Journal, 91 (1081), 646-650. Retrieved from: DOI: http://www.medscape.cpm/viewarticle/853319_ print.

6. Campbell, I.S., \& Fox, C.M. (2012). Options for postgraduate anatomy education in Australia and New Zealand. New Zealand Medical Journal, 125, (1352). 64-73. Retrieved from http://journal.nzma.org.nz/125-1352/5121/.

7. Dai, H., Fang, L., \& Malouin, R.A. (2013). Family Medicine. Training in China. Family Medicine. 45 (5). $341-344$. 
8. De Leeuw, R.A., \& Westerman, M. (2016). Quality specifications in postgraduate medical e-learning: an integrative literature review leading to a postgraduate medical e-learning model. BMC Medical Education, 16, 168. Retrieved from: DOI:10.1186/s12909-016-0400-7.

9. DGME into the Future - A report on FMEC PG Activities / The Future of Medical Education in Canada - postgraduate project / (613) 730-0687. Retrieved from: www.AFMC.CA/FMECPG

10. Farooq, S., \& Quadir, I. (1997). The postgraduate medical education in U.K. The system and its relevance to training and medical practice in Pakistan. Journal of Pakistan Medical Assiciation, 9, 232-236.

11. Forsyth, K. (2009). Critical importance of effective supervision in postgraduate medical education. Med. J. Aust., $191,12-17$. 12. Fraser, A.B., \& Stodel, E.J. (2016). Curriculum reform for residency training: competence, change, and opportunities for leadership. Can. J. Anesth, 63, 875-884. Retrieved from DOI:10.1007/s12630-016-0637-7.

13. Harden, R.M. (2006). Trends and the future of postgraduate medical education. Emerg. Med. J., 23, 798-802. Retrieved from: DOI: $10.1136 / \mathrm{emj} / 2005 / 033738$.

14. Lake, F., \& Ryan, G. (1984). Teaching on the run tips 13: being a good supervisor - preventing problems. Med. J. Aust., 8, 414-415.

15. Lambert, T.J.R. (2004). Multimedia based computer aided learning in postgraduate medical education: The LMF (Luddide mentality Factor) as a barrier to entry Promaco Convention. Reproduced by permission. Retrieved from: http:// cleo.murdoch.edu.au/gen/aset/confs/iims/92/lambert-t.html.Public health

16. Leduc, N., Vanasse, A., \& Scott, I. The career decision-making process of medical students and residents and the choice of specialty and practice location: How does postgraduate medical education fit in? / The Future of Medical Education in Canada - postgraduate project. (613) 730-0687. 241. Retrieved from: www.AFMC.CA/FMECPG

17. Li, J., Wu, Q., \& Yu, T. (2016). Construction of the training mode of the combination of clinical medical professional degree graduate education and resident standardized training. Creative Education, 7, 802-806. Retrieved from: http:// dx.doi.org/10.4236/ce.2016.76082.

18. Li, X., Liu, J., \& Huang, J. (2013). An analysis of the current education status and future training needs of China's rural doctors in 2011. Postgrad. Med., 89, 202-208. Retrieved from: DOI:10.1136/postgradmedj-2012-131094.

19. Ma, S., \& Sood, N.A. (2008). Comparison of the health system in China and India Center for Asia pacific policy. Retrieved from: http://www.rand.org --18

20. Mitchell, R.D., Markwell, A., Fielke, R., Bonning, M.A., Perry, A.W., \& Maor, D. (2011). The 2010 Specialist trainess Survey. MJA. 195 (7), 382.

21. Murray, D.J., \& Boulet, J.R. (2012). Simulation-based curriculum: The breadth of applications in graduate medical education. Journal of Graduate Medical Education, 4 (4), 549-550. Retrieved from: DOI: http:/dx.doi.org/10.4300/ JGME-D-12-00256.1.

22. Nash-Stewart, C. (2010). Medical training providers obtaining feedback from their trainees: what is best practice? Prepared for the Australian Medical Council (AMC) workshop: Training Program Evaluation and Trainee Feedback 13 November 2010. Retrieved from: http://workshop.amc.org.au/wp-content/uploads/2010/10/traine-FeedbackBestPractice-FINAL.pdf).

23. Okereke, C.D. (2000). Mentoring - the trainee's perspective. J. Accid. Emerg. Med., 17, 133-135.

24. Patel, Priyank. (2016). An evaluation of the current patterns and practices of educational supervision in postgraduate medical education in the UK. Perspect Med. Educ., 5, 205-214. Retrieved from: DOI:10.1007/s40037-016-0280-6.

25. Posrgraduate Medical Council of Western Australia website. Education and training page. Retrieved from: http://www. pmcwa.health.wa.gov.au/education/diractors.cfm

26. Postgraduate medical training in Denmark - status and future perspectives (summary in English). (2012). National Board of Health. Denmark. 1-20.

27. Ren, X., Yin, J., \& Wang, B. (2008). A descriptive analysis of medical education in China. Medical Teacher, 30, 667-672. 28. Scheele, F., Van, Lulik S., \& Mulder, H. (2013). Is the modernization of postgraduate medical training in the Netherlands successful? Views of the NVMO Special Interest group on Postgraduate Medical Education. Medical Teacher. Early Online. Retrieved from: DOI: 10.3109/0142159X.2013.849333.

29. Shelker, W., Herbison, P., Belton, A., \& Glue, P. (2013). Factor s related to post graduate retention of medical graduates in New Zealand. The New Zealand Medical Journal, 126 (1371), 27-32. Retrieved from: http: //journal.nzma.org.nz/126$1371 / 5568 /$

30. Shelker, W., Poole, Ph., Bagg, W., Wood, I., \& Glue, P. (2014). Post graduation retention of medical students from Otago and Auckland medical programmes. The New Zealand Medical Journal, 127 (1388), 64-73. Retrieved from: http:// journal.nzma.org.nz/127-1388/5966/

31. Slootweg, I.A. (2016). Teamwork of clinical teachers in postgraduate medical training. Perspect. Med. Educ., 5, 353256. Retrieved from: DOI:10.1007/s40037-016-0286-0.

32. Tsai, J.-C., \& Liu, K.-M. (2008). Evaluation of the effectiveness of postgraduate general medicine training by objective structured clinical examination - Pulot study and reflection on the experiences of Kaohsiung Medical University Hospital. Kaohsiung J. Med. Sci., 24 (12), 627-633.

33. Van, Der Valk Paul. (2016). Quality assurance in postgraduate pathology training the Dutch way: regular assessment, monitoring of training programs but no end of training examination. Virchows Arch., 468, 109-113. Retrieved from: DOI:10.1007/s00428-015-1895-4.

34. VanNieuwenborg, L., \& Goossens, M. (2016). Continuing medical education for general practitioners: a practice format. PGMJ Online First, published on February 5, 2016 as 10.1136/postgradmedj-2015-133662

35. Vickery, A., \& Lake, F. (2005). Teaching on the run tips 10: giving feedback. Med. J. Aust., 183 (5), 267-268.

36. Wilkinson, T.J., Moore, M.L., \& Flynn, E.M. (2012). Professionalism in its time and place - some implications for medical education. New Zealand Medical Journal, 125 (1358), 64-73. Retrieved from: http://journal.nzma.org.nz/125-1358/5262/ 
37. Wilson, A., \& Feyer, A.M. (2015). Final Report - Review of Medical Intern Training (has been prepared as part of the Review of Medical Intern Training, which has been commissioned by the Australian Health Ministers' Advisory Counsil (AHMAC). 51-59.

38. World Federation for Medical Education. (2005). WHO/WFME Guidelines for Accreditation of Basic Medical Education. Geneva / Copenhagen.

39. Wu, L., Wang, Y., \& Peng, X. (2014). Development of a medical academic degree system in China. Medical Education Online. 19 p. Retrieved from: http://dx.doi.org/10.3402/meo.v19.23141.

40. Zhao, Lin Bo, Miyachi, \& Shigeru (2013). Comparison of medical education and requirements for training in the Interventional Neuroradiology in China, Japan and Korea. Neurointervention, 8, 3-8. Retrieved from: http://dx.doi. org/10.5469/neuroin.2013.8.1.3

41. Zhu, J., Li, W., \& Chen, L. Doctors in China: improving quality through modernization of residency education. Retrieved from http: //dx.doi.org/10.1016/50140-6736(16)00582-1.

\section{АНАЛИТИЧЕСКОЕ ИССЛЕДОВАНИЕ МЕЖДУНАРОДНОГО ОПЫТА ОРГАНИЗАЦИИ МЕДИЦИНСКОГО ПОСЛЕДИПЛОМНОГО ОБРАЗОВАНИЯ}

О.Е. Сичкориз

Львовский национальный медицинский университет имени Данила Галицкого, г. Львов, Украина

Цель: аналитическое исследование и изучение опыта организации последипломного медицинского образования в разных странах мира для повышения уровня последипломного образования в Украине.

Материалы и методы. В работе проведено аналитическое исследование литературных источников международного опыта организации последипломного образования в мире.

Результаты. Как известно, в ведущих странах мира опыт подготовки специалистов в области медицины отличается от украинского как по содержанию, так и по объему. Структура медицинского последипломного образования формируется от модели системы здравоохранения в каждой стране, структуры национальной системы здравоохранения, ее фринансирования, экономического развития страны и уровня культуры. Все это приводит к некоторым терминологическим различиям и относительности при сравнении учебных процессов.

Выводы. В развитых странах мира уровень последипломного образования достаточно высокий, однако сегодня наблюдается определенная его стагнация и инертность, что препятствует его прогрессу и совершенствованию в соответствии с современными условиями, которые постоянно меняются. Программы подготовки профессионала-специалиста в развитых странах более разнообразны. Университеты постоянно предлагают широкий спектр программ подготовки.

КЛЮЧЕВЫЕ СЛОВА: последипломное образование; модель подготовки врачей; резидентура; индикатор знаний; организация здравоохранения.

\section{ANALYTICAL RESEARCH OF THE INTERNATIONAL EXPERIENCE OF MEDICAL POSTGRADUATE EDUCATION ORGANIZATION}

O.Ye. Sichkoriz

Danylo Halytskyi Lviv National Medical University, Lviv, Ukraine

Purpose: analytical research and study of the postgraduate medical education organization experience in different countries of the world in order to improve the level of postgraduate education in Ukraine.

Materials and Methods. The paper adduces the analytical research of the literary sources concerning international experience in organizing postgraduate education in the world.

Results. It is well known, that in the leading countries of the world the experience of specialists training in the medical sector differs from Ukrainian in both content and volume. The structure of medical postgraduate education is formed depending on the model of the health care system in each country, the structure of the national health system, its financing, the country's economic development and cultural level. All this leads to some terminological differences and relativity in comparison of learning processes.

Conclusions. In developed countries the level of postgraduate education is rather high, but today some stagnation and inertia are present as well, which impede its progress and improvement according to modern conditions that are constantly changing. Professional training programs in developed countries are more diverse. Universities are constantly offering a wide range of training programs.

KEY WORDS: postgraduate education; doctors training model; residency; knowledge indicator; health care organization.

Рукопис надійшов до редакції 02.11.2017 p.

\section{Відомості про автора:}

Січкоріз Орест Євгенович - кандидат медичних наук, доцент кафедри дитячих інсекційних захворювань, декан фракультету післядипломної освіти Львівського національного медичного університету імені Данила Галицького; тел.: +38(032) 276-93-74. 